\title{
Impairment of Pulmonary Vasoreactivity in Response to Endothelin-1 In Patients With Chronic Obstructive Pulmonary Disease (COPD)
}

\author{
Duong-Quy $\mathrm{S}^{1,2 *}$, Dao $\mathrm{P}^{3}$, Hua-Huy $\mathrm{T}^{1}$, Le-Dong NN4 and Dinh-Xuan $\mathrm{AT}^{1}$ \\ ${ }^{1}$ Department of Respiratory Physiology, Cochin Hospital, University Paris Descartes, Sorbonne Paris Cité, Paris - France \\ ${ }^{2}$ Bio-Medical Research Center, Lam Dong Medical College, Dalat - Vietnam \\ ${ }^{3}$ Antony Hospital, Antony - France \\ ${ }^{4}$ Department of Pulmonology, St. Elisabeth Hospital, Namur - Belgium
}

\begin{abstract}
Background: Pulmonary hypertension secondary to COPD is characterized principally by impairment of vasoreactivity and vascular remodeling. While the structural changes have been described in all stages of COPD, the impairment of vasoreactivity in response to ET-1, a potent vasoconstrictor, has not been well understood.

Materials and methods: Proximal pulmonary arteries were obtained from non-smokers, smokers with normal lung function, and COPD patients who underwent lung resection for other diseases ( $n=6$ in each group). Pulmonary arterial contraction induced by ET-1 was assessed without or with the presence of ET-1 receptor antagonists (BQ123 and $B Q-788)$. Expressions of ET-1 receptors were measured by immunohistochemistry, western blot, and qRTPCR.

Results: ET-1-induced pulmonary arterial contraction increased significantly in COPD patients in comparison with control subjects and non-COPD smokers $(\mathrm{P}<0.05)$ and the use of $E T-1$ receptor antagonists could not prevent this contraction. The hypercontraction was not associated with the increase of ET-1 and ET-1 receptors expression in pulmonary arterial vessels.

Conclusion: In patients with COPD, pulmonary arterial contraction induced by ET-1 has increased significantly and could not be prevented by using ET-1 receptor antagonist alone. This alteration might be related to the upreguation of other signalling pathways in pulmonary arterial vessels of COPD patients.
\end{abstract}

Keywords: COPD; ET-1; ET-1 receptor antagonists; BQ-123; BQ788

\section{Introduction}

In patients with chronic obstructive pulmonary disease (COPD), the impairment of vasoreactivity in response to endothelium-derived constricting factor (endothelin-1, thromboxane) and relaxing factors (nitric oxide, prostacyclin) has not been well understood. This impairment might be due to endothelial dysfunction and might promote to the alteration of pulmonary vascular tone and pulmonary vascular hypertrophy in these patients [1]. Among these vasoreactivity factors, endothelin-1 (ET-1), the most potent endogenous vasoconstrictor peptide of endothelin family, produced by endothelial cells, has an important role in the modulation of vascular resistance.

Moreover, the abnormalities in endotheline-1 (ET-1) metabolism have been also reported in COPD patients. Previous studies showed that the concentration of ET-1 in plasma, in urinary excretion, and in saliva has increased significantly in COPD patients [2]. Further, at local level, the increase of endothelin expression has been founded in pulmonary vessels in patients with pulmonary hypertension secondary to COPD [3]. Although the effect of cigarette smoke on systemic vascular tone due to ET-1 by increasing the vasoconstriction has been well studied [4], the vasoreactivity of pulmonary vessels in response to ET-1 in healthy smokers and especially in smokers with COPD has not been well understood.

Generally, ET-1 exerts its vasoactive properties by binding to its specific receptor $\mathrm{ET}_{\mathrm{A}}$ presenting in pulmonary arterial smooth muscle cells (PASMCs), and $\mathrm{ET}_{\mathrm{B}}$ expressing in endothelial cells (ECs) and in PASMCs. Under normal conditions, ET-1 mediates $\mathrm{Ca}^{2+}$ releasing from sarcoplasmic reticulum, (PKC-dependent inhibition of voltagegated $\mathrm{K}^{+}\left(\mathrm{K}_{\mathrm{v}}\right)$ channels), and subsequent membrane depolarization and $\mathrm{Ca}^{2+}$ influx through voltage-dependent calcium channels [5-7]. This increase in intracellular calcium concentration $\left(\left[\mathrm{Ca}^{2+}\right]_{\mathrm{i}}\right)$ activates myosin light chain kinase (MLCK), leading to phosphorylation of myosin light chains and vasoconstriction $[8,9]$. In chronic hypoxia exposure, where the ET-1 sensitivity and its receptor ET-A have been upregulated [10-12], ET-1-induced vasoconstriction is independently of intracellular calcium concentration and related mostly to $\mathrm{Ca}^{2+}$ -sensitization [13]. Therefore, Ca2+-sensitization regulates vascular tone by increasing phosphorylation of myosin regulatory light chain $\left(\mathrm{MLC}_{20}\right)$ [14]. The use of ET-1 receptor antagonists may prevent the vasoconstriction in hypoxia-induced pulmonary hypertension.

The aims of this study were to evaluate the vasoreactivity of pulmonary arteries in smokers with and without COPD in response to exogenous ET-1 and its receptor inhibitors.

${ }^{*}$ Corresponding author: Duong-Quy S, Cardiology - Respiratory Department Cochin Hospital, Paris Descartes University, Paris - France, Tel: +33.679193377; E-mail: sduongquy.jfvp@gmail.com

Received May 28, 2015; Accepted July 20, 2015; Published July 22, 2015

Citation: Duong-Quy S, Dao P, Hua-Huy T, Le-Dong NN, Dinh-Xuan AT (2015) Impairment of Pulmonary Vasoreactivity in Response to Endothelin-1 In Patients With Chronic Obstructive Pulmonary Disease (COPD). J Vasc Med Surg 3: 213 doi:10.4172/2329-6925.1000213

Copyright: (C) 2015 Duong-Quy S, et al. This is an open-access article distributed under the terms of the Creative Commons Attribution License, which permits unrestricted use, distribution, and reproduction in any medium, provided the original author and source are credited. 


\section{Methods}

\section{Subjects and tissue preparations}

Subjects, who underwent lung resection for other diseases, enrolled in the study. Three groups of subjects were constituted: non-smokers (control subjects), healthy smokers (non-COPD smokers) and smokers with COPD (COPD patients). COPD were defined and classified by the international standard criteria [ratio of $\mathrm{FEV}_{1}$ (forced-expiratory volume in one second)/FVC (forced vital capacity) <0.7] [15]. The study was approved by French Ethnical Committee and taken place in UPRES25511 - Paris Descartes University. All patients were informed about the aims of study and written informed consent was obtained from each subjects.

Proximal pulmonary arterial vessels were dissected precisely far away from local damaged tissues at operation room. Pulmonary arterial rings of 4 to $6 \mathrm{~mm}$ external diameter and $3 \mathrm{~mm}$ of length, cleaned of perivascular tissue, were dissected and immediately putted in Krebs-Henseleit solution at $4^{\circ} \mathrm{C}$ for vasoreactivity study within less than 30 minutes. The others dissected pulmonary arterial vessels were conserved at $-80^{\circ} \mathrm{C}$ for proteins and RNA extractions or fixed in $4 \%$ formalin and embedded in paraffin for immunohistochemistry study.

\section{Chemical reagents and antibodies}

All chemical reagents used in the present study were purchased from Sigma-Aldrich (Sigma-Aldrich France; St Quentin En Fallavier, France) unless otherwise noted. Primary antibody anti-ET ${ }_{A}$ and ET $_{B}$ were purchased from Assay Designs Inc (Ann Arbor, USA).

For all washing steps in immunohistochemical staining and Western blot, phosphate buffered saline (PBS, pH 7.4) was used with Tween $20(0.05 \%)$, noted as PBS-T. Primary antibodies and HRPconjugated secondary antibodies for Western blot were purchased from Santa Cruz Biotechnology Incorporation (Santa Cruz, CA, USA), biotinylated secondary antibodies for immunohistochemical staining from Vector Laboratories (Burlingame, CA, USA), unless differently mentioned. Antibodies used in western blotting were diluted in non-fat milk (5\%), Tween-20 (0.05\%) in PBS and those for immunohistochemistry in PBS.

\section{Measurement of Pulmonary Vascular Contraction}

Pulmonary arterial ring was suspended horizontally between two parallel stainless steel wires for the measurement of isometric tension by organ chambers (Emka Technologies, Paris, France). Pulmonary arterial ring was dipped in a fresh Krebs-Henseleit solution with the following composition: glucose $10 \mathrm{mM}$, pyruvate $2 \mathrm{mM}$, HEPES 10 mM, EDTA $0.03 \mathrm{mM}, \mathrm{NaCl} 118 \mathrm{mM}$, KCl $4.7 \mathrm{mM}, \mathrm{CaCl}_{2} 2.5 \mathrm{mM}$, $\mathrm{KH}_{2} \mathrm{PO}_{4} 1.2 \mathrm{mM}, \mathrm{MgSO}_{4} 1.2 \mathrm{mM}, \mathrm{NaHCO}_{3} 15 \mathrm{mM}$, and the solution was continuously oxygenated with $95 \% \mathrm{O}_{2}-5 \% \mathrm{CO}_{2}$ (Air Liquide Santé; Paris, France) and maintained at $37^{\circ} \mathrm{C}$.

The variations of force generated by the ring segment were measured and recorded by IOX-Software (Emka Technologies, Paris, France). Pulmonary arterial rings were stabilized under controlled condition at $1.0 \mathrm{~g}$ of resting tension (for $10 \mathrm{~min}$ before stretching progressively at $1.5 \mathrm{~g}$ to obtain the pre-tension values as determined by experimental assessments), and it was corresponded to optimal resting tension for isometric condition registry. After the initial equilibration period, the vessels were exposed to a maximally effective concentration of $80 \mathrm{mM} \mathrm{KCl}$. When a stable tension plateau developed, the $\mathrm{KCl}$ was removed by several washes and a period of $30 \mathrm{~min}$ was allowed for reequilibration. Then, pulmonary arterial rings were exposed to increasing and cumulative doses of ET- $1\left(10^{-10}\right.$ to $\left.10^{-7} \mathrm{M}\right)$, in the present of inhibitors of $\mathrm{ET}_{\mathrm{A}}$ receptor (BQ-123 at $10^{-6} \mathrm{M}$ ) or $\mathrm{ET}_{\mathrm{B}}$ receptor (BQ788 at $\left.10^{-6} \mathrm{M}\right)$. Other pulmonary arterial rings of the same patients were incubated with receptor inhibitors during at least 1 hour before starting the measurement of ET-1 dose-response curve. The isometric contractions were normalized by expressing force developed per cross-sectional area $\left(\mathrm{g} / \mathrm{mm}^{2}\right)$, which took into account the variation in vascular sizes.

The integrity of pulmonary arterial endothelial cells was tested by the vasodilatation endothelium-dependent in response to 10 ${ }^{6} \mathrm{M}$ acetylcholine (Ach) at the end of ET-1 stimulation protocol and when the plateau of contraction curve had been obtained at 10 ${ }^{7} \mathrm{M}$. The relaxation of more than $30 \%$ compared to the value before acetylcholine response was necessary to confirm the endothelial intact. The ET-1 response-curve had been presented as the percentage of maximal contraction induced by $80 \mathrm{mM}$ potassium chloride $(\mathrm{KCl})$. For each patient, four pulmonary arterial rings were studied.

\section{Immunohistochemistry for $\mathrm{ET}_{\mathrm{A}}$ and $\mathrm{ET}_{\mathrm{B}}$ receptors}

For immunohistochemical staining of $\mathrm{ET}_{\mathrm{A}}$ and $\mathrm{ET}_{\mathrm{B}}$ receptors, after re-hydration by successive baths of decreasing ethanol concentrations, all pulmonary arterial sections had been submerged in citrate buffer ( $10 \mathrm{mM}$ citrate, $0.05 \%$ Tween, and $\mathrm{pH} 6.0$ ) and unmasked with heat treatment in micro-own $(750 \mathrm{~W} \times 3$ times $)$. Endogenous peroxidase activity was neutralized by incubating with oxygenate water of $3 \%$ during 15 minutes. The non-specific endogenous binding sites had been blocked by $2 \%$ BSA (bovine serum albumin) in 45 minutes. After washing steps, pulmonary arterial sections had been incubated for one hour with primary antibodies, which had been diluted to $1 / 50$ for anti$\mathrm{ET}_{\mathrm{A}}$ and $1 / 25$ for anti-ET ${ }_{\mathrm{B}}$ in PBS-T of $0.05 \%$ and $1 \% \mathrm{BSA}$ as titration essays. Negative-control sections were incubated in blocking buffer alone without primary antibody. The sections had been then incubated with biotinylated secondary antibody at $1 / 200$ dilution within 45 minutes. After successive washing steps, pulmonary arterial sections were incubated with preformed avidin-peroxydase RTU Vectastain Kit (Vector Laboratory; Burlingame, USA) before revealed with metal enhanced $\mathrm{DAB}$ peroxidase substrate (3, 3'-diaminobenzidine) until the desired staining was obtained ( 4 minutes for ET $\mathrm{A}_{\mathrm{A}}$ and 5 minutes for $\mathrm{ET}_{\mathrm{B}}$ ). Tissue sections were then counterstained with hematoxylinGill solution and examined using light microscopy. $\mathrm{ET}_{\mathrm{A}}$ and $\mathrm{ET}_{\mathrm{B}}$ immunostaining expression was measured in endothelial and SMC cells of proximal pulmonary arteries. The staining expression was measured by using intensity score. At least ten counted images were performed for each patient.

\section{Real time PCR for mRNA of ET-1, ET-1 conversion enzyme, and $\mathrm{ET}_{\mathrm{A}}$ and $\mathrm{ET}_{\mathrm{B}}$ receptors}

Pulmonary arteries for real time PCR experiments were frozen in liquid nitrogen and stored at $-80^{\circ} \mathrm{C}$. The samples were homogenated and realized ARN extraction in RNase-free condition by using combined phenol-guanidine isothiocynate buffer (Trizol •, Life technologies, CA, USA). Each sample had been homogenated in Trizol at $4^{\circ} \mathrm{C}$ with Ultraturrax (T25, Staufen, Germany), centrifuged at $12000 \times \mathrm{g}$ within 10 minutes to eliminate tissue debris, and then added with chloroform (Merck, Darmstadt, Germany) to the lysate. After precipitated with isopropanol (Merck, Darmstadt, Germany) and centrifugated at 14000 $\times \mathrm{g}(10 \mathrm{~min})$, RNA pellet had been washed with $70 \%$ ethanol (Merck, 
Hohenbrunn, Germany) and centrifugated at $12000 \times$ g. Pellet had been then redissolve in RNase-free water and quantified with optical density at $260 \mathrm{~nm}$.

After RNA isolation, reverse transcription was carried out in mixed solution of $7.5 \mu \mathrm{M}$ hexanucleotide, $9 \mathrm{mM}$ dithiotreitol, $20 \mathrm{U}$ RNase inhibitor (Perkin-Elmer), 4 dNTP with the concentration of $220 \mu \mathrm{M}$ for each (Boehringer), and $50 \mathrm{U}$ Reverse Transcriptase (Superscript; Gibco BRL). It had been placed in PCR apparatus (Perkin-Elmer Gene Amp PCR system 2400 , CA, USA) with following cycles: $10 \mathrm{~min}$ at $22^{\circ} \mathrm{C}, 1$ hour at $42^{\circ} \mathrm{C}$, and $5 \mathrm{~min}$ at $99^{\circ} \mathrm{C}$. Real time PCR was performed with the real time PCR GeneAmp machine 7700. The GeneAmp machine 7700 sequence detection system monitored the binding of a fluorescent dye to double-strand DNA by real time detection of the fluorescence during each cycle of PCR amplification. Control samples without the reverse-transcription step and no added RNA were also included in each plate to detect any possible contamination. The housekeeping genes, HPRT (Hypoxanthine PhosphoRibosyl Transférase) was used as references. The real time PCR reaction was performed at a temperature of $50^{\circ} \mathrm{C}$ for $2 \mathrm{~min}, 95^{\circ} \mathrm{C}$ for $10 \mathrm{~min}$, and the following 40 PCR cycles with $95^{\circ} \mathrm{C}$ for $15 \mathrm{~s}$ and $60^{\circ} \mathrm{C}$ for $1 \mathrm{~min}$, and fluorescence was measured after amplification step.

The sequences of the primer pairs were designed as follows: ET-1: forward 5'-CTTCTGCCACCTGGACATCA- 3' and reverse 5'-GGCTTCCAAGTCCATACGGA-3'; ET receptor: forward 5'-TGGTGTGCACTGCGATCTTC-3' and reverse 5'-GCAATTCTCAAGCTGCCATTC-3'; ET $_{\text {в }}$ receptor: forward 5'-TGGCGTATTTCTTTGCAAGCT-3' and reverse 5'-AGGTTGAGGACGGTGATCCC-3'; ECE-1: forward 5'-TGGGGGACCTTCAGCAACCT-3', reverse 5'-GGGTGTCCTGGAGTTGTCCTTG-3'; HPRT: forward 5'-TCAGGCAGTATAATCAAAGATGGT-3' and reverse 5'-AGTCTGGCTTATATCCAACACTTCG-3'.

At the end of each PCR run, the data were automatically analyzed by the system and an amplification plot was generated for each DNA sample. Quantitative real-time PCR values are expressed as the fold change of the target-gene expression relative to HPRT mRNA in each sample using the following formula: fold change $=2^{-\Delta \Delta \mathrm{CT}}$, where $\Delta \mathrm{C}_{\mathrm{T}}=$ $\mathrm{C}_{\text {Ttarget gene }}-\mathrm{C}_{\mathrm{HPRT}}$ and $-\Delta \Delta \mathrm{C}_{\mathrm{T}}=\Delta \mathrm{C}_{\mathrm{Ttest} \mathrm{sample}}-\Delta \mathrm{C}_{\mathrm{Tcontrol}}$. The experimental approach was further validated by the observation that the differences between the $C_{T}$ for the target gene and $\beta$-actin remained essentially constant for each starting DNA amount.

\section{Western blot analysis for $\mathrm{ET}-1$ receptors $\left(\mathrm{ET}_{\mathrm{A}}, \mathrm{ET}_{\mathrm{B}}\right)$}

Frozen pulmonary arterial samples were homogenized in icecold RIPA buffer (Cell Signalling Technology, Danvers, USA). The homogenates were centrifuged at $21000 \mathrm{~g}$ at $4^{\circ} \mathrm{C}$ for 20 minutes to remove tissue debris. Protein contents of homogenated lysates were measured by BCA Protein assay kit (Pierce Biotechnology, Rockford, IL, USA). Equal amounts of lysates ( $30 \mu \mathrm{g}$ of total protein content per sample), were subjected to electrophoresis on SDS-PAGE gels $\left(12 \%\right.$ for $\mathrm{ET}_{\mathrm{A}}$ and $\left.\mathrm{ET}_{\mathrm{B}}\right)$, and then transferred to PVDF membranes (Immobilon-P, Millipore, MA, USA). Membranes were blocked in 5\% non-fat milk, $0.1 \%$ Twen-20 in PBS for 1 hour at room temperature and then hybridized overnight at $4^{\circ} \mathrm{C}$ with primary antibodies diluted at $1 / 500$. After being washed in PBS-T, membranes were incubated with HRP-linked goat anti-rabbit, diluted at 1/10000. Protein bands were developed on the film by using Enhanced ChemiLuminescence Plus reagent, according to the manufacturer's instructions (Amersham, Biosciences, Orsay, France). The protein density was quantified by using Image Software System (Genius 2). The equal amounts of proteins loaded per well were verified by stripping the blots with Tris- $\mathrm{HCl}(\mathrm{pH}$ 6.7) $62.5 \mathrm{mM}$, SDS $2 \%$, and $\beta$-mercapto-ethanol $100 \mathrm{mM}$ for 30 minutes at $55^{\circ} \mathrm{C}$. The membranes were reprobed with a mouse polyclonal anti$\beta$-actin antibody (1/1000; sc-9104, Santa Cruz Biotechnology) and then incubated with HRP-linked goat anti-rabbit, diluted at $1 / 10000$. Results were expressed as ratios of $\mathrm{ET}_{\mathrm{A}}$ and $\mathrm{ET}_{\mathrm{B}} / \beta$-actin.

\section{Statistical analysis}

Statistical comparisons were performed with non parametric Kruskal-Wallis test and with analysis of variance (ANOVA) among more than three groups by using the SPSS 16.0 software (Chicago, IL). Data were presented as means \pm SD. Differences were considered significant with $\mathrm{P}<0.05$.

\section{Results}

\section{Clinical characteristics}

Three groups of patients who met the inclusion criteria were included in the present study (6 subjects for each group). The clinical and functional characteristics of the patients are presented in Table 1. The tobacco consumption in COPD patients was higher than nonCOPD smokers $(\mathrm{P}<0.05)$. The non-COPD smokers had a normal lung function with $\mathrm{FEV}_{1}=97 \pm 5 \%$ and $\mathrm{FEV}_{1} / \mathrm{FVC}=75 \pm 4 \%$. COPD patients had moderate airflow obstruction with $\mathrm{FEV}_{1}=73 \pm 15 \%$ and $\mathrm{FEV}_{1} /$ $\mathrm{FVC}=64 \pm 6 \%$. All the patients of three groups had a normal gas blood exchange.

\section{Vasoconstriction induced by ET-1}

The results of contraction induced by ET-1 with increasing concentration $\left(10^{-10}-10^{-7} \mathrm{M}\right)$ in organ bath chambers showed that in compare to Emax (contraction induced by $80 \mathrm{mM} \mathrm{KCl}$ ) and with the high dose $\left(10^{-8}-10^{-7} \mathrm{M}\right)$, the percentage of maximal contraction was significantly higher in COPD patients than controls and non-COPD smokers $(\mathrm{P}<0.05$; Figure 1$)$. Whereas, with the lose dose $\left(10^{-10}-10^{-9}\right.$ $\mathrm{M})$, there were not any significant differences between three groups in response to ET-1 ( $\mathrm{P}>0.05$; Figure 1$)$.

\section{Effect of $\mathrm{ET}_{\mathrm{A}}$ and $\mathrm{ET}_{\mathrm{B}}$ antagonists in ET-1-induced contraction}

To determine the role of $\mathrm{ET}_{\mathrm{A}}$ or $\mathrm{ET}_{\mathrm{B}}$ receptor involved in the ET-1 induced-contraction, in the present study, the pulmonary arterial rings had been exposed to selective antagonist of $\mathrm{ET}_{\mathrm{A}}$ receptor (BQ-123 at $10^{-6} \mathrm{M}$ ) and $\mathrm{ET}_{\mathrm{B}}$ receptor (BQ-788 at $10^{-6} \mathrm{M}$ ) in organ bath chambers.

In control group, in the presence of BQ-123 and BQ-788, the percentage of pulmonary arterial contraction induced by ET-1 was

\begin{tabular}{|c|c|c|c|c|}
\hline Variables & $\begin{array}{c}\text { Control } \\
\text { (non smoking) }\end{array}$ & $\begin{array}{c}\text { Smokers } \\
\text { non-COPD }\end{array}$ & COPD & $\mathbf{P}$ \\
\hline & $(n=6)$ & $(n=6)$ & $(n=6)$ & \\
\hline Age, years & $59 \pm 7$ & $50 \pm 10$ & $67 \pm 12$ & $\mathrm{NS}^{+, \neq}$ \\
\hline Male/Female & $2 / 4$ & $3 / 3$ & $3 / 3$ & \\
\hline Tobacco, pack-year & - & $30 \pm 13$ & $41 \pm 23$ & $<0.05^{+}$ \\
\hline $\mathrm{FEV}_{1}, \%$ pred & $97 \pm 5$ & $97 \pm 5$ & $73 \pm 15$ & $<0.05^{\mathrm{T}, \mathrm{f}}$ \\
\hline $\mathrm{FEV}_{1} / \mathrm{FVC}$ & $86 \pm 5$ & $75 \pm 4$ & $64 \pm 6$ & $N S,<0.05^{1,+}$ \\
\hline FVC, \% pred & $105 \pm 17$ & $104 \pm 9$ & $87 \pm 22$ & NS \\
\hline $\mathrm{PaO}_{2}, \mathrm{mmHg}$ & $86 \pm 11$ & $87 \pm 17$ & $83 \pm 14$ & NS \\
\hline $\mathrm{PaCO}_{2}, \mathrm{mmHg}$ & $38 \pm 2$ & $37 \pm 2$ & $37 \pm 5$ & NS \\
\hline
\end{tabular}

(\%pred : percentage of predicted value; $\mathrm{FEV}_{1}$ indicates forced expiratory volume in one second; FVC, forced vital capacity; ${ }^{*}$ : non-COPD smokers vs controls; t: COPD vs control subjects; :: COPD vs non-COPD smokers; NS: no significant)

Table 1: Clinical characteristics of study subjects. 


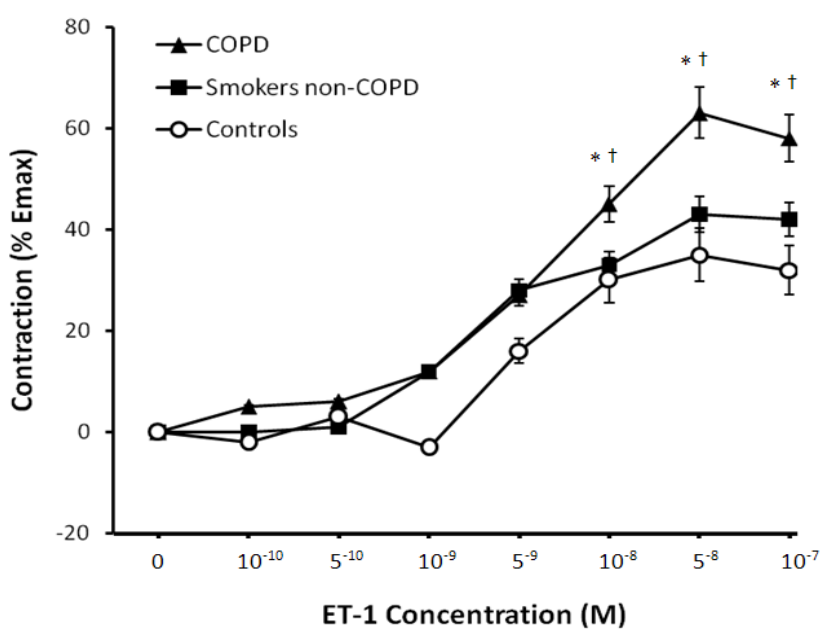

Figure 1: ET-1-induced contraction of pulmonary arterial rings with increased dose in controls, non-COPD smokers, and COPD patients ( $n=6$ in each group). Emax is represented as a contraction level induced by $80 \mathrm{mM}$ of $\mathrm{KCl}$. Values are means $\pm \mathrm{SE}$. ${ }^{*}+\mathrm{t} \mathrm{P}<0.05$ for COPD vs. control subjects and non-COPD smokers.

significantly reduced in comparison without antagonists $(\mathrm{P}<0.05$; Figure 2a). In non-COPD smokers, the contraction had been reduced significantly in the presence of BQ-123. Whereas, in the presence of BQ-788, the pulmonary arterial contraction induced by ET-1 had two phases: reduced the contraction at low dose $\left(10^{-10}-10^{-8} \mathrm{M}\right)$, and increased the contraction at high dose $\left(10^{-8}-10^{-7} \mathrm{M}\right)$; but there were not any significant differences in comparison with ET-1-induced contraction without BQ-788 ( $>0.05$; Figure $2 b$ ). In COPD patients, the reductions of pulmonary arterial contraction induced by ET-1 in the presence of BQ-123 and BQ-788 were not significantly different in comparison with ET-1-induced contraction without antagonists ( $\mathrm{P}>0.05$; Figure 2c).

Semi-quantitative and quantitative assessment of $\mathrm{ET}_{\mathrm{A}}$ and $\mathrm{ET}_{\mathrm{B}}$ receptors

Immunohistochemistry: The results of immunostaining $\mathrm{ET}_{\mathrm{A}}$ and $\mathrm{ET}_{\mathrm{B}}$ receptor expression in pulmonary arterial sections showed that there were no significant differences between non-COPD and COPD smokers for expression intensity per surface unit assessment and in comparison with control group ( $\mathrm{P}>0.05$; Figure $3 \mathrm{a})$.

Western blot: The protein expression of $\mathrm{ET}_{\mathrm{A}}$ and $\mathrm{ET}_{\mathrm{B}}$ receptor measured by densitometry showed that there were no significant differences between three groups for protein levels ( $\mathrm{P}>0.05$; Figure $3 \mathrm{~b}$ ).

Real time quantity-PCR (RTq-PCR): Although the contractions of pulmonary arterial rings induced by ET-1 were different between non-COPD and COPD smokers, the results of RTq-PCR showed that there were no significant differences between three groups for the transcription of mRNA ( $>0.05$; Figure $3 \mathrm{c})$.

The relative expressions of ET-1 and ET-1 enzyme conversion (EEC) were not significant different between three groups. Although the mRNA expression of ET-1 and EEC in non-COPD smokers were slightly higher than controls and COPD patients, but there were not any significant differences $(\mathrm{P}>0.05$; data not shown).

\section{Discussion}

The aim of this study was to elucidate the role of $\mathrm{ET}_{\mathrm{A}}$ and $\mathrm{ET}_{\mathrm{B}}$ receptors in pulmonary arteries responding to ET-1 induced vasoconstriction in non-COPD smokers and in COPD patients. The results of present study showed that: (1) in COPD patients, the pulmonary vasoconstriction induced by ET-1 was significantly increased in comparison with non-smokers and non-COPD smokers; (2) ET-1-induced vasoconstriction was mediated by $\mathrm{ET}_{\mathrm{A}}$ and $\mathrm{ET}_{\mathrm{B}}$ in non-smokers and predominantly by $\mathrm{ET}_{\mathrm{A}}$ in non-COPD smokers; (3) in COPD patients, vasoconstriction induced by ET-1 was not completely inhibited by selective ET-1 receptor antagonists.

Until now, the effect of cigarette smoking on the tonus of

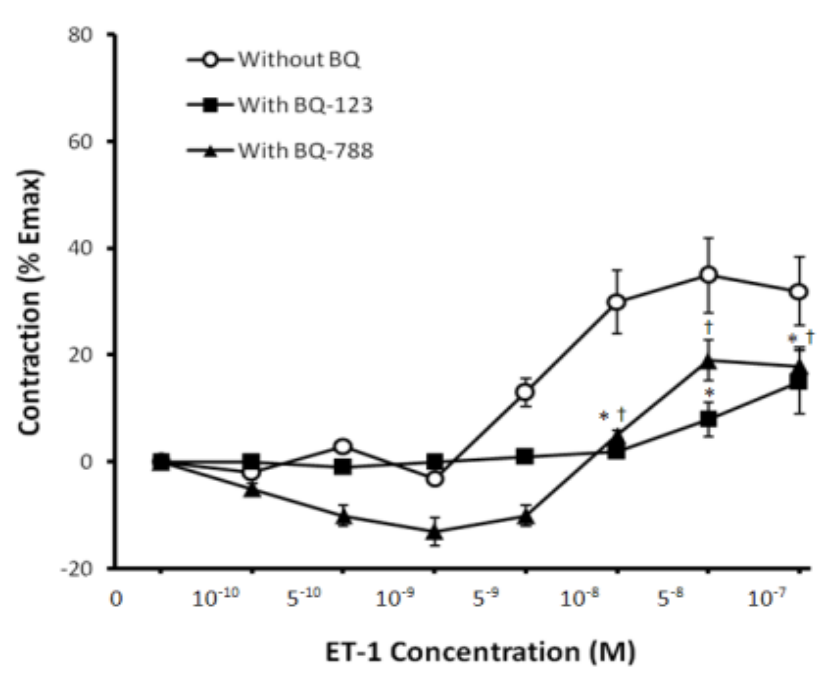

Figure 2a: ET-1-induced contraction of pulmonary arterial rings with increased dose in the presence of $\mathrm{ET}_{\mathrm{A}}(\mathrm{BQ}-123)$ and $\mathrm{ET}_{\mathrm{B}}(\mathrm{BQ}-788)$ antagonists in control subjects (4 measurement for each patient). Emax is represented as a contraction level induced by $80 \mathrm{mM}$ of $\mathrm{KCl}$. Values are means $\pm S E$. ",$: P<0.05$ for $B Q-123$ and $B Q-788$ vs. without antagonists.

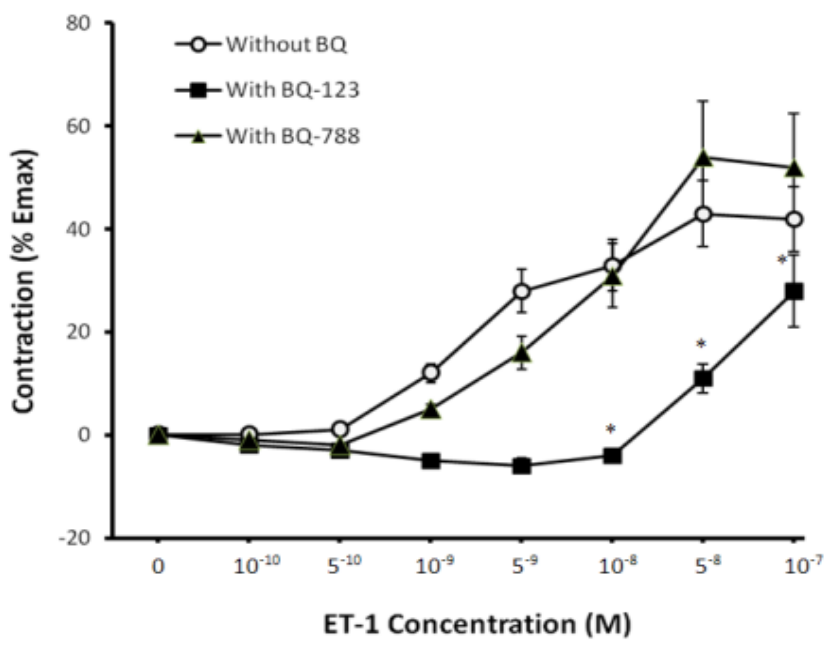

Figure 2b: ET-1-induced contraction of pulmonary arterial rings with increased dose in the presence of $\mathrm{ET}_{\mathrm{A}}(\mathrm{BQ}-123)$ and $\mathrm{ET}_{\mathrm{B}}(\mathrm{BQ}-788)$ antagonists in non-COPD smokers (4 measurement for each patient). Emax is represented as a contraction level induced by $80 \mathrm{mM}$ of $\mathrm{KCl}$. Values are means $\pm S E$. : $: P<0.05$ for $B Q-123$ vs. without antagonists. 


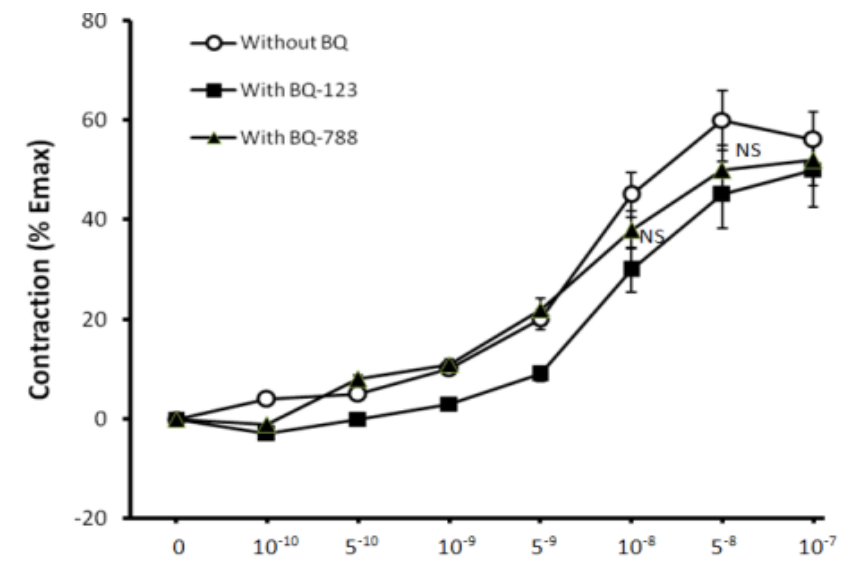

ET-1 Concentration (M)

Figure 2c: ET-1-induced contraction of pulmonary arterial rings with increased dose in the presence of $\mathrm{ET}_{\mathrm{A}}$ (BQ-123) and $\mathrm{ET}_{\mathrm{B}}$ (BQ-788) antagonists in COPD patients (4 measurement for each patient). Emax is represented as a contraction level induced by $80 \mathrm{mM}$ of $\mathrm{KCl}$. Values are means \pm SE. NS : no significant differences with $P>0.05$ for $B Q-123$ and $\mathrm{BQ}-788$ vs without antagonists.
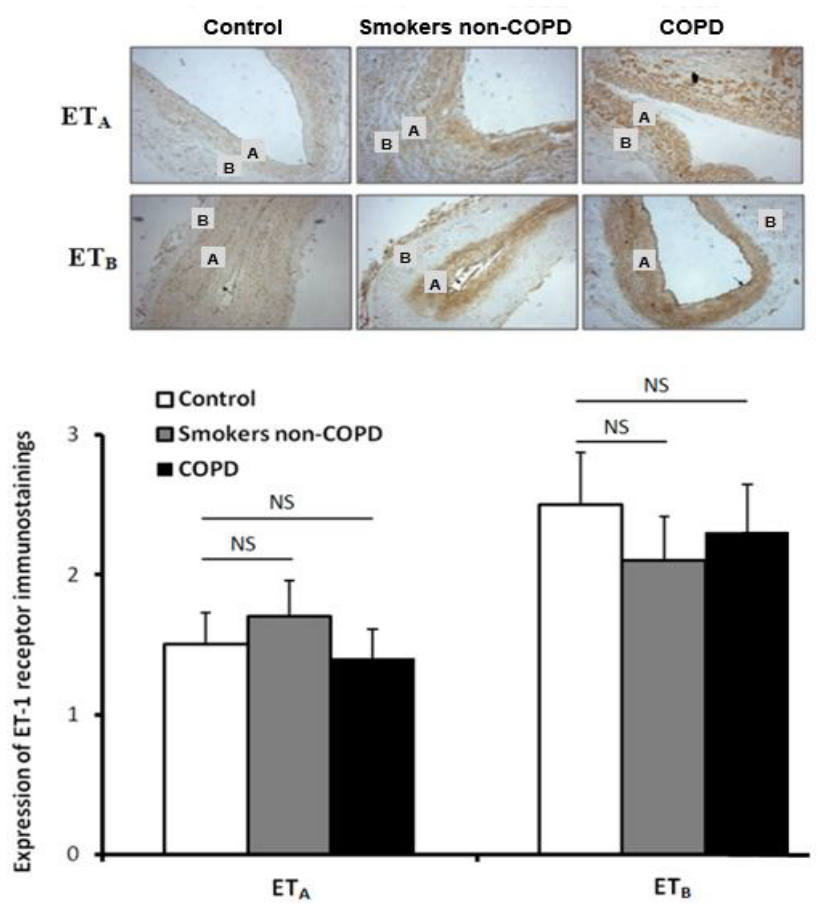

Figure 3a: Expression of $E T_{A}$ and $E T_{B}$ receptors measured by immunohistochemistry in pulmonary arterial vessels in control, non-COPD smokers, and COPD patients (magnification $\times 10$ ). There were no significant differences between three groups ( $n=6$ in each group). A: adventi; B: media. NS: no significant difference vs. control subjects with $P>0.05$.

pulmonary arterial vessels induced by ET-1 in COPD has not been completely clarified. In COPD, the pulmonary vascular tone has been changed progressively due to the disturbance of vasodilatation - vasoconstriction balance. This event starts at early stage of disease and becomes more severe in advanced stage patients where the alveolar hypoxia and vascular remodelling has been established [16]. Among the endothelium-derived contracting factors, ET-1 has an important role. The previous studies showed that the plasma concentration of ET-1 and the expression of $\mathrm{ET}_{\mathrm{A}}$ receptor have been increased in chronic hypoxic exposure and in COPD with hypoxia, and it was associated with the alteration of ET-1-induced vasoconstriction [1719]. The mechanism by which ET-1 is upregulated in COPD has not been completely understood. It might be partially mediated by oxidative stress due to cigarette smoke or by alveolar hypoxia when the disease is in progress. In the present study, although ET-1-induced pulmonary vasoconstriction had been founded in all the three groups, the vasoconstriction in response to ET- 1 at high doses $\left(\geq 10^{-8} \mathrm{M}\right)$ was significantly higher in COPD patients than control subjects and nonCOPD smokers (Figure 1). Whereas, ET-1-induced vasoconstriction in non-COPD smokers was slightly higher than control, but there were no significant difference (Figure 1). These results suggested that the contractility of pulmonary arteries with ET-1 was higher in COPD patients.

In the present study, the use ofET-1 antagonists reduced significantly the contraction induced by ET-1 in non-smokers (BQ-123 for $\mathrm{ET}_{\mathrm{A}}$ and

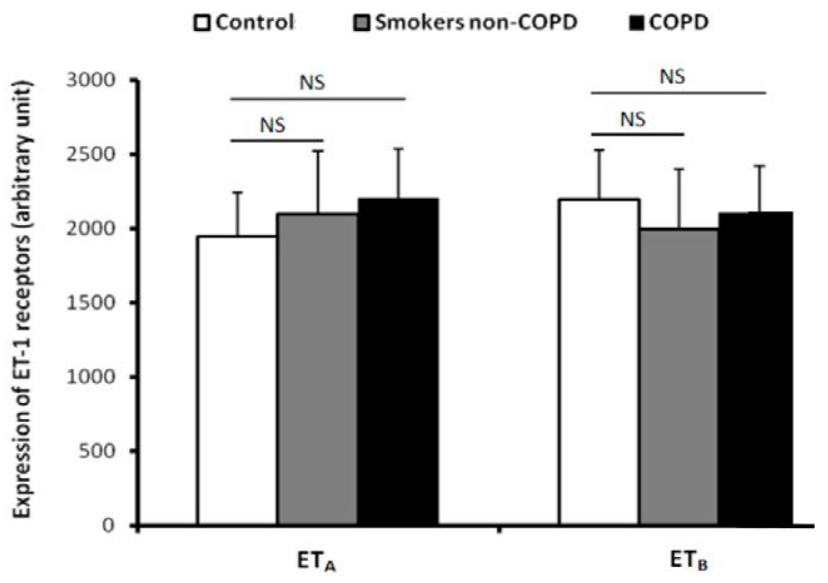

Figure 3b: Expression of $E T_{A}$ and $E T_{B}$ receptors measured by western blot in pulmonary arterial vessels in control, non-COPD smokers, and COPD patients. There were no significant differences between three groups $(n=6$ in each group). NS: no significant difference vs. control subjects with $P>0.05$.

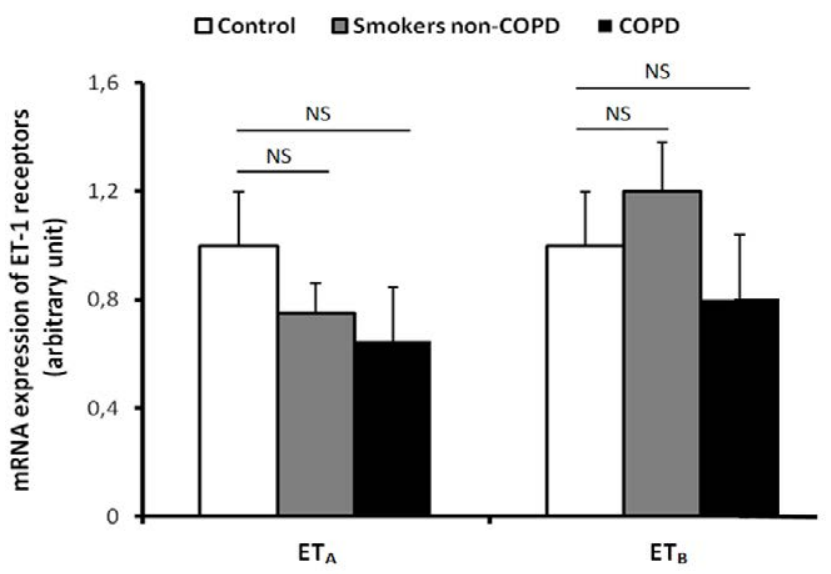

Figure 3c: Expression of $E T_{A}$ and $E T_{B}$ mRNA quantified by RT-PCR in pulmonary arterial vessels in control, non-COPD smokers, and COPD patients. There were no significant differences between three groups $(n=6$ in each group). NS: no significant difference vs. control subjects with $P>0.05$. 
BQ-788 for $\mathrm{ET}_{\mathrm{B}}$ ) and in non-COPD smokers (BQ-123 for $\mathrm{ET}_{\mathrm{A}}$ ) (Figure $2 \mathrm{a}-\mathrm{b}$ ). But the contractions were not different in COPD patients (Figure 2c). It confirmed that in non-smokers, the vasoconstriction responded to ET-1 was completely mediated by two receptor types $\left(\mathrm{ET}_{\mathrm{A}}\right.$ and $\mathrm{ET}_{\mathrm{B}}$ ) and the selective antagonists abolished this effect. However, in non-COPD smokers, $\mathrm{ET}_{\mathrm{A}}$ receptor had a predominant role in ET1 -induced pulmonary vasoconstriction (Figure $2 \mathrm{~b}$ ). Particularly, in COPD patients, although the contraction induced by ET-1 at a high dose was significantly higher than non-smokers and non-COPD smokers, ET-1 receptor antagonists could not reduce significantly the contraction (Figure 2c). In addition, in the present study, the mRNA expression of ET-1 and its receptors $\mathrm{ET}_{\mathrm{A}}$ and $\mathrm{ET}_{\mathrm{B}}$ were not different between three groups (Figure 3a-c). It suggested that in COPD, the pulmonary arterial contraction in response to ET-1 was not related directly to the upregulation of $\mathrm{ET}_{\mathrm{A}}$ and $\mathrm{ET}_{\mathrm{B}}$ receptors. In our study, we could not measure the plasma concentration of ET-1 of study patients to assess the correlation between the level of mRNA-ET-1 expression in pulmonary arterial vessels and the plasma concentration of ET-1. As discussed above, the plasma concentration of ET-1 was increased and associated with the upregulation of $\mathrm{ET}_{\mathrm{A}}$ expression and the alteration of vasoconstriction in COPD with hypoxemia. These data may explain why in our study, gene expression of ET-1 and its receptors was not increased significantly in COPD without hypoxemia.

In this study, the use of selective ET-1 receptor antagonists did not decrease the contraction of pulmonary arterial vessels induced by ET-1 in non-COPD smokers (for BQ788) and in COPD patients (for both BQ123 and BQ789) suggested that another pathway had been implicated in this phenomena. Under normal condition, vasoconstriction induced by ET-1 is mediated by $\mathrm{Ca}^{2+}$ influx through L-type $\mathrm{Ca}^{2+}$ channels and $\mathrm{Ca}^{2+}$ release from the sarcoplasmic reticulum [20]. In some conditions such as in hypoxia exposure, ET-1-induced contraction is independent of changes in $\left[\mathrm{Ca}^{2+}\right]_{\mathrm{i}}[21]$, and known as $\mathrm{Ca}^{2+}$ sensitization of the contractile apparatus.

In summary, the results of present study might be explained that in non-smokers (control subjects), ET-1-induced pulmonary arterial contraction was mediated by $\mathrm{ET}_{\mathrm{A}}$ and $\mathrm{ET}_{\mathrm{B}}$ receptors and this contraction was inhibited by the use of either $\mathrm{ET}_{\mathrm{A}}$ or $\mathrm{ET}_{\mathrm{B}}$ receptor antagonist. In non-COPD smokers, ET-1-induced pulmonary arterial contraction was mediated principally via $\mathrm{ET}_{\mathrm{A}}$ receptor. Whereas, in COPD patients, either $\mathrm{ET}_{\mathrm{A}}$ or $\mathrm{ET}_{\mathrm{B}}$ receptor antagonist could not decrease significantly the contraction induced by ET-1. In these patients, the ET-1-induced pulmonary arterial contraction was not mediated via $\mathrm{ET}_{\mathrm{A}}$ or $\mathrm{ET}_{\mathrm{B}}$ receptor. In these patients, when stimulated with ET-1, the vasoconstriction might be mediated by another signaling pathway such as RhoA/Rho-kinase pathway. The activity of this pathway has been upregulated in healthy smoker and smokers with COPD [22, 23] and the use of Rho-kinase inhibitor might attenuated significantly the effect of ET-1 [24].

\section{Conclusion}

Although carried out in the limit of patient number, the present study demonstrated that in patients with COPD, the contraction of pulmonary arterial vessels induced byET- 1 was not completely mediated via ET-1 receptors. Especially, in these patients, the hypercontraction induced by ET-1 was not associated with the upregulation of the mRNA expression of ET-1. However, others studies must be done to clarify the role of other pathways in ET-1-induced pulmonary arterial vasoconstriction in patients with COPD.

\section{References}

1. Duong-Quy S (2013) Chronic Smoking and Vascular Disease: What Can we Hope for the Future? J Vasc Med Surg 1: 113.
2. Celik G, Karabiyikaylu G (1998) Local and peripheral plasma endothelin-1 in pulmonary hypertension secondary to chronic obstructive pulmonary disease. Respiration 65: 289-294.

3. Giaid A, Yanagisawa M, Langleben D, Michel RP, Levy R, et al. (1993) Expression of endothelin-1 in the lungs of patients with pulmonary hypertension. N Engl J Med 328: 1732-1739.

4. Kiowski W, Linder L, Stoschitzky K, Pfisterer M, Burckhardt D, et al. (1994) Diminished vascular response to inhibition of endothelium-derived nitric oxide and enhanced vasoconstriction to exogenously administered endothelin-1 in clinically healthy smokers. Circulation 90(1):27-34

5. Salter KJ, Wilson CM, Kato K, Kozlowski RZ (1998) Endothelin-1, delayed rectifier $\mathrm{K}$ channels, and pulmonary arterial smooth muscle. J Cardiovasc Pharmacol 31 Suppl 1: S81-83.

6. Shimoda LA, Sylvester JT, Booth GM, Shimoda TH, Meeker S, et al. (2001) Inhibition of voltage-gated $\mathrm{K}(+)$ currents by endothelin-1 in human pulmonary arterial myocytes. Am J Physiol Lung Cell Mol Physiol 281: L1115-1122.

7. Shimoda LA, Sylvester JT, Sham JS (2000) Mobilization of intracellular $\mathrm{Ca}(2+)$ by endothelin-1 in rat intrapulmonary arterial smooth muscle cells. Am Physiol Lung Cell Mol Physiol 278: L157-164.

8. Somlyo AP, Somlyo AV (1994) Signal transduction and regulation in smooth muscle. Nature 372: 231-236.

9. Somlyo AP, Somlyo AV (2000) Signal transduction by G-proteins, rho-kinase and protein phosphatase to smooth muscle and non-muscle myosin II. J Physiol 522 Pt 2: 177-185.

10. Eddahibi S, Raffestin B, Braquet P, Chabrier PE, Adnot S (1991) Pulmonary vascular reactivity to endothelin-1 in normal and chronically pulmonary hypertensive rats. J Cardiovasc Pharmacol 17 Suppl 7: S358-361.

11. McCulloch KM, Docherty C, MacLean MR (1998) Endothelin receptors mediating contraction of rat and human pulmonary resistance arteries: effect of chronic hypoxia in the rat. Br J Pharmacol 123: 1621-1630.

12. Resta TC, Walker BR (1996) Chronic hypoxia selectively augments endothelium-dependent pulmonary arterial vasodilation. Am J Physiol 270 H888-896.

13. Shimoda LA, Sham JS, Shimoda TH, Sylvester JT (2000) L-type Ca(2+) channels, resting $[\mathrm{Ca}(2+)](\mathrm{i})$, and $\mathrm{ET}-1$-induced responses in chronically hypoxic pulmonary myocytes. Am J Physiol Lung Cell Mol Physiol 279: L884-894.

14. Somlyo AP, Somlyo AV (2003) Ca2+ sensitivity of smooth muscle and nonmuscle myosin II: modulated by $\mathrm{G}$ proteins, kinases, and myosin phosphatase. Physio Rev 83: 1325-1358.

15. Rabe KF, Hurd S, Anzueto A, Barnes PJ, Buist SA et al. (2007) Global Initiative for Chronic Obstructive Lung Disease. Global strategy for the diagnosis management, and prevention of chronic obstructive pulmonary disease: GOLD executive summary. Am J Respir Crit Care Med 176: 532-55.

16. Santos S, Peinado VI, Ramírez J, Melgosa T, Roca J, et al. (2002) Characterization of pulmonary vascular remodelling in smokers and patients with mild COPD. Eur Respir J 19: 632-638.

17. Eddahibi S, Raffestin B, Braquet P, Chabrier PE, Adnot S (1991) Pulmonary vascular reactivity to endothelin-1 in normal and chronically pulmonary hypertensive rats. J Cardiovasc Pharmacol 17 Suppl 7: S358-361.

18. McCulloch KM, Docherty C, MacLean MR (1998) Endothelin receptors mediating contraction of rat and human pulmonary resistance arteries: effect of chronic hypoxia in the rat. $\mathrm{Br} \mathrm{J}$ Pharmacol 123: 1621-1630.

19. Resta TC, Walker BR (1996) Chronic hypoxia selectively augments endothelium-dependent pulmonary arterial vasodilation. Am J Physiol 270 H888-896.

20. Pollock DM, Keith TL, Highsmith RF (1995) Endothelin receptors and calcium signaling. FASEB J 9: 1196-1204.

21. Shimoda LA, Sham JS, Shimoda TH, Sylvester JT (2000) L-type $\mathrm{Ca}(2+)$ channels resting $[\mathrm{Ca}(2+)](\mathrm{i})$, and $\mathrm{ET}-1$-induced responses in chronically hypoxic pulmonary myocytes. Am J Physiol Lung Cell Mol Physiol 279: L884-894.

22. Duong-Quy S, Dao P, Hua-Huy T, Guilluy C, Pacaud P, et al. (2011) Increased Rho-kinase expression and activity and pulmonary endothelial dysfunction in smokers with normal lung function. Eur Respir J 37: 349-355.

23. Bei Y, Duong-Quy S, Hua-Huy T, Dao P, Le-Dong NN, et al. (2013) Activation of RhoA/Rho-kinase pathway accounts for pulmonary endothelial dysfunction in patients with chronic obstructive pulmonary disease. Physiol Rep 1: e00105.

24. Duong-Quy S, Bei Y, Liu Z, Dinh-Xuan AT (2013) Role of Rho-kinase and its inhibitors in pulmonary hypertension. Pharmacol Ther 137: 352-364. 